\title{
Sağlık Çalışanları Yapay Zekaya Hazır mı?
}

\author{
Are healthcare workers ready for artificial intelligence?
}

S. Ayhan ÇALIŞKAN ${ }^{* 1}$, Ozan KARACA ${ }^{1}$, Kadir DEMIR ${ }^{2}$

Sayın Editör,

Sağlık bilimlerinde yapay zeka araştırmaları ile bu araştırma sonuçlarından yararlanılarak geliştirilip sağlık hizmeti kullanımına sunulan ürünler ve uygulamalar geniş bir yelpazeye yayılmaktadır. Sağlık verilerinin toplanması, sınıflanması, yorumlanması, bu verileri kullanarak laboratuvar verilerinin (örneğin, radyolojik ve patolojik görüntülerin) işlenmesi ile elde edilen bilgilerin tıbbi ve cerrahi tedaviyi destekleyici olarak kullanılması bu geniş çerçevenin içinde yer almaktadır. Ayrıca tüm bu aşamalar hakkında hastanın ve ilgili sağlık çalışanlarının bilgilendirilmesi, gerektiğinde erken uyarılması da sürecin önemli bir parçasıdır. Bu çerçeveden bakıldığında tıp ve sağlık bilimleri alanında yapay zekanın kullanımı ve görünürlüğü giderek artmaktadır.

Yapay zeka birçok meslek için ciddi bir tehdit unsuru olarak algılanırken yapay zekanın özellikle sağlık bakım hizmetinde birincil araç, doğrudan teşhis koyucu veya tedaviye ilişkin karar verici olmasını engelleyen nedir? Bu sorunun öncelikli yanıtı, hekimlerin hastanın durumu ile uyum gösteren (adaptif), hastayı anladığını açık ve anlaşılır biçimde sergileyebilmesini sağlayan, uzun evrim sürecinde kazandığı "doğal” iletişim ve empati yetenekleridir.

Buna ek olarak; sağlık çalışanlarının tanı koyarken, tedavi planlarken veya girişimsel uygulamalar sırasında -yapay zekanın eğitim veri setlerinde yer almayan farklılıklar nedeniyle göz ardı edebileceği- gerçek dünyaya ilişkin çok değişkenli durumları da klinik karar verme sürecinde kullanabilmesi gibi bilişsel becerileri de önemli unsurlardır. $\mathrm{Bu}$ soruya verilebilecek diğer bir yanıt ise yapay zeka uygulamaları sonucu oluşabilecek hatalı tıbbi uygulamalar (tıbbi malpraktis) ve sonuçlarının sorumlusunun kim olacağına ilişkin etik boyut tartışmasıdır.

Yapay zeka uygulamaları aslında; tanı koymada, tedavi planlamada, cerrahi girişimlerde sağlık çalışanlarının destek olan yararlı bir asistan, bir kolaylaştırıcı ve daha geniş kitlelere sağlık hizmeti sunulmasını sağlayan bir yardımcı, tıbbi malpraktis oranını azaltıcı rolü olan araçlardır. Sağlık alanında mesleklerarası iletişimin verimli yürütüldüğü bir klinikte sağlık hizmetine katkı sunan yapay zeka uygulamasını, klinik ortamda çalışan bir (sanal) sağlık profesyoneli gibi görmek gerektiğini bir betimleme olarak sunmak, sağlıkta yapay zeka dönüşümünün yarattığı "sağlık çalışanlarının yerine geçebilir" alg1sını değiştirmek için çok yararlı olacaktır.

Bu çerçeveden bakıldığında tüm sağlık çalışanlarının ve öğrencilerinin yapay zeka uygulamaları ve sağlık hizmetlerinde kullanılması konusunda farkındalıklarının artırılması için çalışmalar yapılması, eğitim programları geliştirilerek mezuniyet öncesi, mezuniyet sonrası ve sürekli mesleki gelişim etkinliği olarak uygulanmasına gereksinim vardır. Bu çalışmalar sağlık çalışanlarının yapay zeka uygulamaları konusunda bilgi ve deneyimlerini artırarak onların bu konuda kendilerini daha yetkin ve "hazır" hissetmelerini sağlayacaktır.

Received/Geliş : 11.03.2021

Accepted/Kabul: 31.03 .2021

Publication date: 15.04 .2021

S. Ayhan ÇALIŞKAN

* ayhan.caliskan@ege.edu.tr

${ }^{1}$ Ege Üniversitesi Tıp Fakültesi,

Tıp Eğitimi Anabilim Dalı, Bornova, İzmir

ORCID: 0000-0001-9714-6249

Ozan KARACA

${ }^{1}$ Ege Üniversitesi Tıp Fakültesi, Tıp Eğitimi Anabilim Dalı, Bornova, İzmir

ORCID: 0000-0001-5431-0942

Dr. Kadir DEMIR

${ }^{2}$ Dokuz Eylül Üniversitesi, Buca Eğitim Fakültesi, Bilgisayar ve Öğretim Teknolojileri Eğitimi Bölümü, Bornova, İzmir

ORCID: 0000-0001-9568-9450 